\title{
Using of Ceratophyllum demersum I. for lead and cadmium pollution removal by columns technology
}

\begin{abstract}
Environmental exposure to toxic heavy metals is one of the main critical issues on environmental and public health. Heavy metals are common pollutants in aquatic ecosystems, which are particularly susceptible and often final receptor of heavy metals. Phytoremediation with aquatic plants is a new, effective and inexpensive method for improving water quality and wastewater. In this study, Lead and Cadmium (50ppm) of industrial water polluted were removed by the aquatic plant, Ceratophyllum demersum L., as grinded and crushed. Results showed that grinded plant was the best in removing Lead and Cadmium than crushed plant, so, removing concentration of Lead by Ceratophyllum demersum L. grinded and crushed were $(38,37.8,37.5,33.1$ and 30.8), $(23,22.5,22.5$, 18.4 and 12.2) ppm and removal percentage (76, 75.6, 75, 66.2 and 61.6), (46, 45, 45, 36.8 and 24.4$) \%$ at flow rate $(5,10,15,20$ and 25$) \mathrm{ml} / \mathrm{min}$ respectively. Whereas, removing concentration of Cadmium were (29.5, 29.5, 30, 22.5 and 14.4), (13, 12.5, 12.5, 8.4 and 2.2) ppm and removal percentage $(59,59,60,45$ and 28.8$),(26,25,25,16.8$ and 4.4$) \%$ at flow rate $(5,10,15,20$ and 25$) \mathrm{ml} / \mathrm{min}$ respectively.
\end{abstract}

Keywords: ceratophyllum demersum, lead, cadmium, water pollution
Volume 6 Issue I - 2018

\author{
Mokdad M Jawad, Eman H Abed, Hisham K \\ Oudah \\ Environment and water Directorate, Ministry of Science and
} Technology, Baghdad, Iraq

Correspondence: Eman H Abed, Environment and water Directorate, Ministry of Science and Technology, Baghdad, Iraq, Email hishamalshweli@yahoo.com

Received: January 09, 2017 | Published: January 17, 2018

\section{Introduction}

Environmental pollutant and its harmful effect on ecology have been studied intensively during the last decades. The removing of pollutants from wastewater was increased with the fast industrial development. These wastewaters are produced in large amounts and must be treated before discharge. ${ }^{1}$

Heavy metals are very harmful for humans, animals and plants. Global and local agencies have therefore established certain limits on the quantities of heavy metals being that discharged into the environment. The most widely used methods for removing heavy metals are chemical or electrochemical precipitation, both of which pose a significant problem in terms of disposal of the precipitated wastes. $^{2}$

When heavy metals are could be high accumulate in living tissues, Cadmium, lead and copper can become a sanitary and ecological threat to drinking water resources, even at very low concentrations. Cadmium and zinc are common industrial pollutants, as well as their harmful effect to plant at relatively low concentrations. ${ }^{3}$ Thus, there was a need to use cleaner alternatives must be developed in order to remove heavy metals from effluents. ${ }^{4}$ Occurrence of water polluted with toxic metals in plants and human being water bodies adversely affects the lives of local people since they utilize this water for daily requirements. The heavy metals can be incorporated into the food chain and their levels can increase through biological magnification. ${ }^{5}$

Studies indicate that there are many plants that can drag and accumulate of heavy metals from contaminated areas, but the ideal plant for this process should be as specific features available, such as the pace of growth and roots, mass and ease of harvesting and cutting and accumulation of a wide range of elements, in addition to carry around high levels of these elements. ${ }^{6}$

Lead $(\mathrm{Pb})$, cadmium $(\mathrm{Cd})$, cobalt $(\mathrm{Co})$, chromium $(\mathrm{Cr})$ and mercury $(\mathrm{Hg})$, which have the toxic effects of high concentration as well as low concentrations of plants. Lead is accounted significant pollutant due to solubility in water, which results in wide distribution in the aquatic ecosystems lead, is strongly toxic to organisms. The excessive amounts of lead in water cause many physiological and biochemical stress symptoms in plants, such as growth reduction, disturbed mineral nutrition, water imbalance and growth productivity and root elongation. When they enter inside the cell wall like any other heavy metals they produce an oxidative stress in plant and lead to cell damage. ${ }^{7}$ The aim of this study was to use Ceratophyllum demersum and its ability on wastewater for recycling to reuse for other purposes in agriculture and industrial fields.

\section{Materials and methods}

\section{Plant collection}

Samples of the plant $C$. demersum L. were collected from existing channels at Baghdad University, during April and May 2017. Then the plant dried by using oven at $65^{\circ} \mathrm{C}$ for three days, then breathing and grinding. The plant filled in a glass column prepared for this purpose in the laboratory.

\section{Adsorption column preparation}

Glass columns used with a diameter $(7 \mathrm{~cm})$ and $(50 \mathrm{~cm})$ length filled with grinded and crushed $C$. demersum plant. Filter paper was put at the end and the beginning of each column. The two columns are joined with container (5) liter capacity of each, in order to feed the column with polluted water with (Lead and Cadmium) at a flow rate $(15 \mathrm{ml} / \mathrm{min})$ of first container while the $2^{\text {nd }}$ for aggregation water after recycle in column at approximately $(5,5 \mathrm{hrs})$ impairment time.

\section{The biological treatment system design(designed bioremediation system):}

The form of (Figure 1), which were established in the laboratory for the treatment of water contaminated with heavy metals using 
a glass column container for each of them grinded and crushed $C$. demersum L separately. The system is composed of:

a. Glass column with a diameter $(7 \mathrm{~cm})$ and filled with the flora demersum L. crushed or grinded (50 cm length).

b. Iron holder to install column.

c. Heavy metals' polluted water with heavy elements tank, (5L) capacity.

d. Water tank after treatment (5L) capacity.

e. Connecting pipelines; to connect the parts of the system.

f. Valves to regulate the flow rate of the contaminated water.

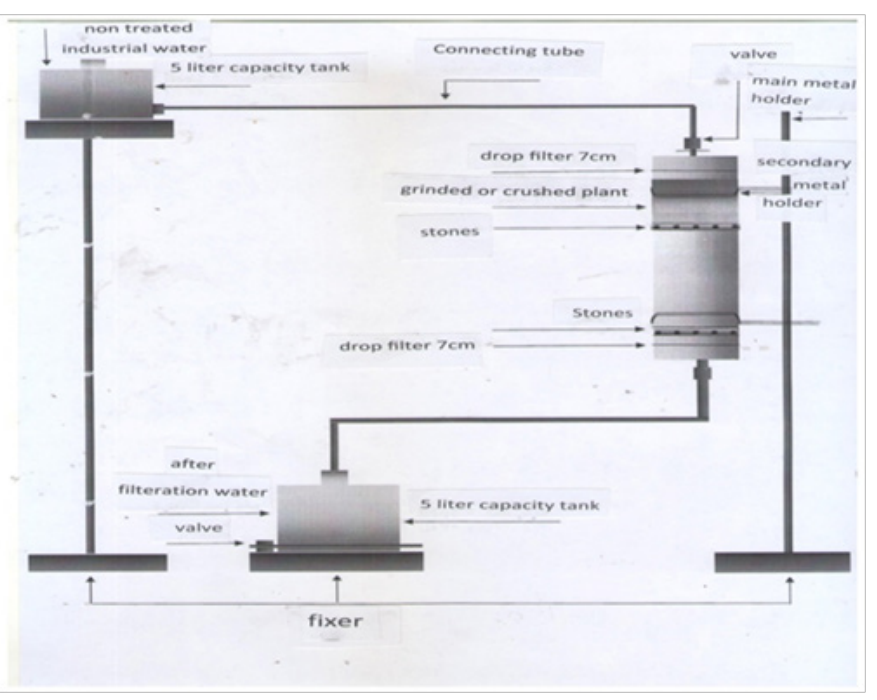

Figure I Diagram of immobile adsorption column.

\section{Results and discussion}

\section{Removal of lead by grinded and crushed of $C$. demersum L}

Removal of lead element with concentration $(50 \mathrm{ppm})$ by grinded and crushed plant $C$. demersum $\mathrm{L}$. from polluted water by using adsorbent column with different flow rate ranged $(5,10,15,20$ and 25) $\mathrm{ml} / \mathrm{min}$. Results shown that the best removal of a vital element for lead by using grinded $C$. demersum $\mathrm{L}$. which was obtained at flow rate $(5,10$ and 15$) \mathrm{ml} / \mathrm{min}$, with percentage of removal (76, 75.5 and 75$) \%$, respectively, whereas, the crushed plant was a decent efficiency in removal the Lead with $(46,45,45,36.8$ and 24.4$) \%$ at flow rate $(5,10,15,20$ and 25$) \mathrm{ml} / \mathrm{min}$, respectively (Table 1) (Figure 2). Phytoremediation, a method to remove pollutants from the environment by using plants and algae, has been known as a promising cost-effective and environmentally sustainable technology for the remediation of water polluted by toxic trace elements.

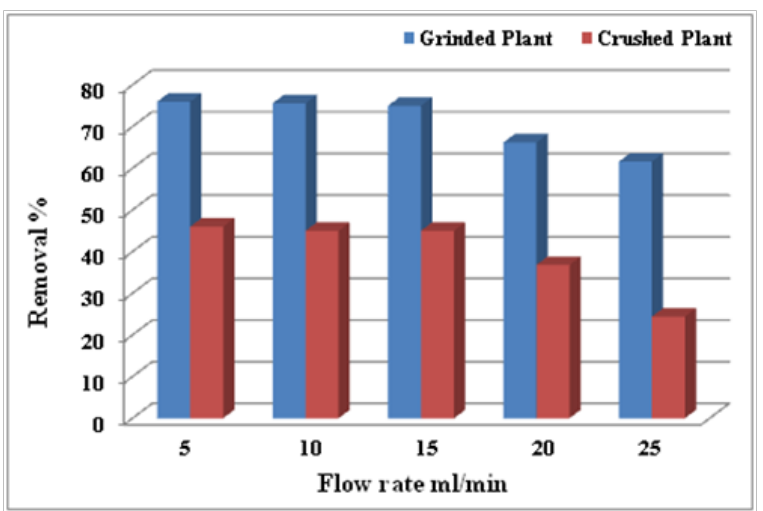

Figure 2 Removal percentage of Lead (50ppm) by grinded and crushed of $C$. demersum L. at different flow rate.

Table I Clinical and biochemical variables of individuals with overweight-obesity

\begin{tabular}{lllllll}
\hline \multicolumn{2}{l}{ Con. of lead $(\mathbf{p p m})$ after treating } & \multicolumn{2}{l}{ Removing con. of lead (ppm) } & \multicolumn{2}{l}{ Removal \% } & Flow rate \\
\cline { 1 - 5 } Grinded & Crushed & Grinded & Crushed & Grinded & Crushed & \\
\hline 12 & 27 & 38 & 23 & 76 & 46 & 5 \\
12.2 & 27.5 & 37.8 & 22.5 & 75.6 & 45 & 10 \\
12.5 & 27.5 & 37.5 & 22.5 & 75 & 45 & 15 \\
16.9 & 31.6 & 33.1 & 18.4 & 66.2 & 36.8 & 20 \\
19.2 & 37.8 & 30.8 & 12.2 & 61.6 & 24.4 & 25
\end{tabular}

$S D$, standard deviation; $B M I$, body mass index; WC, waist circumference; $A C$, abdominal circumference; $H C$, hip circumference; RER, respiratory exchange ratio; HR, hear rate.

\section{Remove of cadmium by C. demersum L. grinded and crushed column}

The polluted water with Cadmium element (50ppm) in adsorption experiments column of grinded and crushed $C$. demersum $\mathrm{L}$ plant was removed by grinded plant with $(59,59$ and 60$) \%$ at flow rate $(5,10$ and 15) $\mathrm{ml} / \mathrm{min}$ respectively, whereas, the crushed plant was a decent efficiency in removal the Cadmium with $(26,25,25,16.8$ and 4.4) $\%$ at flow rate $(5,10,15,20$ and 25$) \mathrm{ml} / \mathrm{min}$, respectively, (Table 2) (Figure 3), and the best flow rate in removing Lead and Cadmium by grinded and crushed plant $C$. demersum L. were $(5,10$ and 15) $\mathrm{ml} /$ $\min$.
The $C$. demersum L. plant has the ability to absorb and accumulate a large amount of Lead and Cadmium, which makes it useful as indicators of biological weapons. It has proven its ability cumulative Cadmium in contaminated water up to $1000 \mathrm{ppm} .{ }^{8}$ Index bio indicator for this type of plant on the viability of deals in reducing water pollution with heavy metals. ${ }^{9}$ Some environmental scientists improve that this type of aquatic plants $(C$. demersum $\mathrm{L}$.) have the ability to remove the bullets Lead, Nickel and Cadmium more than the rest of Iron, Manganese and Zinc. ${ }^{10}$ Studies have shown that the greatest potential to alleviate damage metals from sewage that address activities by absorption and desorption of surface water plants. [11,12 Also dangerous element Cadmium is not limited to small organisms 
even on humans. ${ }^{13,14}$ The plant water $C$. demersum L. has the ability to adsorption and carrying toxic heavy metals. ${ }^{15}$ From these results observed that the percentage removal of Lead from the solution when used aquatic plants $C$. demersum are high. These results are in accordance with Majid and Siddique. ${ }^{16,17}$

Table 2 Removal of Cadmium (50ppm) using packaged treatment C. demersum L. grinded and crushed at different flow rates

\begin{tabular}{|c|c|c|c|c|c|c|}
\hline \multicolumn{2}{|c|}{ Con. of cadmium (ppm) after treating } & \multicolumn{2}{|c|}{ Removing con. of cadmium (ppm) } & \multicolumn{2}{|c|}{ Removal \% } & \multirow{2}{*}{$\begin{array}{l}\text { Flow } \\
\text { rate }\end{array}$} \\
\hline Grinded & Crushed & Grinded & Crushed & Grinded & Crushed & \\
\hline 20.5 & 37 & $2950.00 \%$ & 13 & 59 & 26 & 5 \\
\hline 20.5 & 37.5 & $2950.00 \%$ & 12.5 & 59 & 25 & 10 \\
\hline 20 & 37.5 & 30 & 12.5 & 60 & 25 & 15 \\
\hline 27.5 & 41.6 & 22.5 & 8.4 & 45 & 16.8 & 20 \\
\hline 35.6 & 47.8 & 14.4 & 2.2 & 28.8 & 4.4 & 25 \\
\hline
\end{tabular}

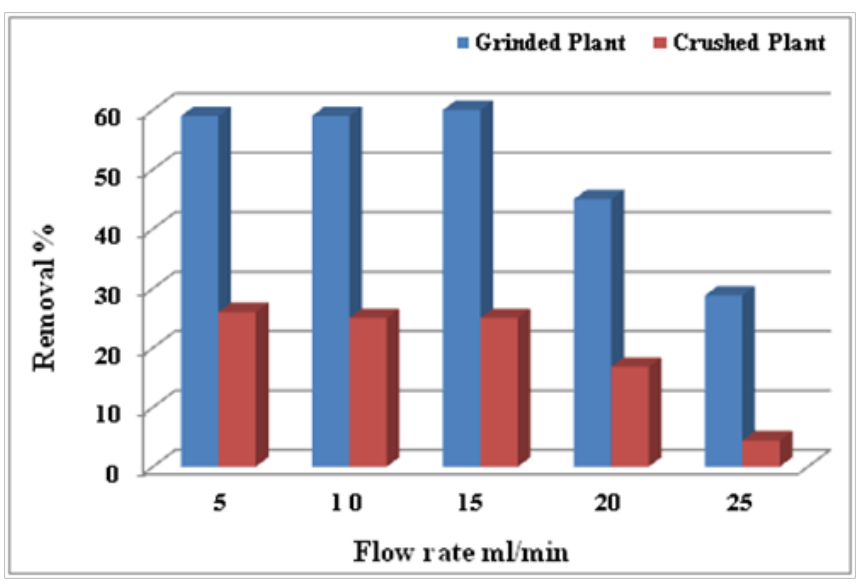

Figure 3 Removal percentage of Cadmium (50ppm) by grinded and crushed of $C$. demersum L. at different flow rate.

\section{Conclusion}

We conclude from this study on the ability of aquatic plants to remove some heavy elements from industrial water that cause environmental pollution. The grinded of $C$. demersum $\mathrm{L}$. plant proved to be efficient in removal of Lead and Cadmium than crushed plant, when packed in a glass column with a flow rate of $(5,10$ and 15$) \mathrm{ml} /$ $\min$.

\section{Acknowledgements}

None.

\section{Conflict of interest}

The author declares no conflict of interest.

\section{References}

1. Ozdemir C, Karatas M, Dursun S, et al. Effect of $\mathrm{MnSO}_{4}$ on the chromium removal from leather industry wastewater. Environ Technol. 2005;26(4):397-400.

2. Meunier N, Drogui P, Montané C, et al. Comparison between electro coagulation and chemical precipitation for metals removal from acidic soil leachate. J Hazard Mater. 2006;137(1):581-590.

3. Chakravarty B, Srivastava S. Toxicity of some heavy metal in vivo and in vitro Helianthus annuus. Mutation Research. 1992;283(4):287-294.
4. Volesky B. Sorption and Biosorption. Canada: BV Sorbex Inc; 2003.

5. Cardwell AJ, Hawker DW, Greenway M. Metal accumulation in aquatic macrophytes from southeast Queensland, Australia. Chemosphere. 2002;48(7):653-663.

6. Alkorta I, Hernandez-Allica J, Becerril JM, et al. Recent findings on the phytoremediation of soils contaminated with environmentally toxic heavy metals and metalloids such as zinc, cadmium, lead, and arsenic. Environmental Science and Bio/Technology. 2004;3(1):71-90.

7. Sharma P, Dubey RS. Lead toxicity in plants. Braz J Plant Physiol. 2005;17(1):35-52.

8. Gafta D, Mount ford JO. Manual de interpret are a habitatelor Nature 2000 din Romania [Romanian Manual for Interpretation of EU Habitats]. Risoprint: Cluj-Napoca; 2008. 104 p.

9. Chigbo FE, Smith RW, Shore FL. Uptake of arsenic, cadmium, lead and mercury from polluted waters by the water hyacinth Eichhornia crassipes. Environ Pollut. 1982;27:181-193.

10. Zimmels Y, Kirzhner F, Kadmon A. Effect of circulation and aeration on wastewater treatment by floating aquatic plants. Separation and Purification Technology. 2009;66(3):570-577.

11. Shaham J, Meltzer A, Ashkenazi R, et al. Biological monitoring of exposure to cadmium, a human carcinogen, as a result of active and passive smoking. J Occupy Environ Med Dec. 1996;38(12):1220-1228.

12. Palmer KC, Mari F, Malian MS. Cadmium-induced acute lung injury: compromised repair response following thyroidectomy. Environ Res Dec. 1986;41(2):568-584.

13. Nawrot T, Plusquin M, Hogervorst J, et al. Environmental exposure to cadmium and risk of cancer:a prospective opulation-based study. Lancet On col. 2006;7(2):119-126.

14. Woolhouse HW. Toxicity and tolerance in the responses of plants to metals. In: Lange OL, Nobel PS, editors. Encyclopedia of Plant Physiology, New Series, Physiological Plant Ecology III, Responses to The Chemical and Biological Environment. Berlin: Springer-Verlag; 1983:12C.

15. Matache ML, Marin C, Rozylowicz L, et al. Plants accumulating heavy metals in the Danube River Wetlands. Journal of environmental health Science and engineering. 2013;11(1):39.

16. Majid A, Siddique N. Phytoremediation using Eichhorinacrassipes aquatic plants. The Nucleus. 2013;50(3):267-277.

17. Razinger J, Dermastia M, Drinovec L, et al. Antioxidative responses of duckweed (Lemna minor) to short-term copper exposure. Environ Sci Pollut Res. 2007;14:194-201. 